\title{
O099: Making a training CD-ROM on activity waste at risk care
}

\author{
B Chardon \\ From 2nd International Conference on Prevention and Infection Control (ICPIC 2013) \\ Geneva, Switzerland. 25-28 June 2013
}

\section{Introduction}

Within the context of a mission of the regional Health/ Environment departments, CEDDES produced a second training CD-ROM in november 2010, about hazardous health care waste : infectious, chemical, toxic, radioactive waste.

\section{Objectives}

To respond to needs for training the different categories of staff in health care, education establishments, research centres in human medicine and veterinary, and professionals of the environment, in order to set up an optimal health care waste management.

\section{Methods}

Stages :

- Selection of the Steering Committee - period of the mission : 18 months

- Document retrieval

- Writing

\section{Results}

Production of a CD-rom of 400 screens divided in 5 chapters: $\mathrm{HCW}$, infectious $\mathrm{HCW}$, chemical, toxic $\mathrm{HCW}$, radioactive $\mathrm{HCW}$, general waste; illustrated with 300 photos; glossary of 250 words; repertoire of 240 acronyms; proposals for evaluation quiz; selection of websites.

\section{Conclusion}

The CD-rom can be used in developed countries as well as developing ones.

A suitable HCWM is a complex system with regulatory, organizational, structural, budgetary components;

CEDDES, Montpellier, France with sanitary, environmental, economic, legal implications.

Key elements: - Hand hygiene, control of health care associated infections, in the context of the new world stakes of patient safety; - Management of sharps and AES control.

The CD-rom is a teaching aid to set up a long-lasting change of behaviour towards a common culture of safety. It got the Prize 2012 of the STHSS.

\section{Disclosure of interest}

None declared.

Published: 20 June 2013

doi:10.1186/2047-2994-2-S1-099

Cite this article as: Chardon: O099: Making a training CD-ROM on activity waste at risk care. Antimicrobial Resistance and Infection Control 2013 2(Suppl 1):099.
Submit your next manuscript to BioMed Central and take full advantage of:

- Convenient online submission

- Thorough peer review

- No space constraints or color figure charges

- Immediate publication on acceptance

- Inclusion in PubMed, CAS, Scopus and Google Scholar

- Research which is freely available for redistribution

Submit your manuscript at www.biomedcentral.com/submit
() Biomed Central

\section{Biomed Central}

